\title{
SOIL BIOTA ASSOCIATED WITH ENDOPHYTE- INFECTED TALL FESCUE IN THE FIELD
}

\author{
A.J. POPAY and J.G. JENSEN \\ AgResearch, Ruakura Research Centre, Private Bag 3123, Hamilton, \\ New Zealand \\ Email:alison.popay@agresearch.co.nz.
}

\begin{abstract}
Invertebrates present in soil samples taken from plots of tall fescue (Festuca arundinacea) infected with two non-toxic strains of Neotyphodium endophyte (AR501 and AR542) at Aorangi near Palmerston North and one strain (AR501) at Lincoln in Canterbury, together with endophyte-free controls at both sites, were determined in autumn 2002. Roots taken from these samples were stained and checked for the presence of arbuscular mycorrhiza. At Lincoln, numbers of root aphid (Aploneura lentisci) associated with plants infected with AR501 were significantly less than those on endophyte-free plants, while grass grub numbers (Costelytra zealandica) did not differ between treatments. Beneficial invertebrates, Collembola, mites and earthworms, were not affected by endophyte at either site and neither was colonisation of roots by mycorrhiza.
\end{abstract}

Keywords: grass grub, Collembola, mites, Aploneura lentisci, earthworms, mycorrhiza, Festuca arundinacea, Neotyphodium.

\section{INTRODUCTION}

Tall fescue (Festuca arundinacea) cultivars used in pastoral agriculture in New Zealand have, until recently, been free from infection by Neotyphodium fungal endophytes of grasses because of the animal toxicity associated with the presence of this fungus. During the 1990s, strains of endophyte were found that do not produce the mammalian toxins. These have been evaluated for their agronomic and pest protection properties in field trials at five sites around New Zealand.

These field trials provided an opportunity to assess the effect that endophyte infection has, not just on insect pests, but also on beneficial invertebrates, principally those associated with decomposition in the soil. The associations that plants form with the arbuscular mycorrhizas (AM) are another important environmental aspect to consider. These fungi can increase the ability of plants to forage for nutrients in soil, although grasses show little reliance on AM except under phosphorous-limiting conditions. Sayer et al. (2004) and Bell (2005) have reported on, respectively, the micro-organisms and nematodes found in roots and soil samples taken from the tall fescue plots at two of the field trial sites, Aorangi near Palmerston North and at Lincoln in Canterbury. In this paper information is presented on soil invertebrates, other than nematodes, that were taken from the same samples and the presence of AM in the roots. The invertebrates include rootfeeding pests such as grass grub (Costelyra zealandica) and the root aphid, Aploneura lentisci, as well as organisms such as mites (Acari), earthworms and Collembola that are involved in decomposition processes.

\section{Field trials and sampling}

\section{METHODS}

The trial at Aorangi, near Palmerston North was on a Kairanga silt loam and the one at Lincoln in Canterbury on a Wakanui silt loam. Both trials had been sown into $5 \times 3$ m plots in the autumn of 1997 with treatments arranged in a randomised block design. Management of the trials was similar, with regular grazing and fertiliser applications. 
At both sites, four replicate plots each of tall fescue cv. Grasslands Advance without endophyte (E-), or infected (E+) with the endophyte AR501, were sampled. In addition, two plots containing 'Advance breeding pool' infected with the endophyte AR542 were sampled at Aorangi. Sampling was carried out in 2002 on 11 March at Aorangi and on 8 April at Lincoln by taking 5 soil cores, $100 \mathrm{~mm}$ in diameter and $100 \mathrm{~mm}$ deep, from each plot. Samples were sent immediately to Ruakura Research Centre for processing.

Tillers were removed from the soil cores and the proportion of these infected with endophyte was determined using tissue immunoblot (Hahn et al. 2003). In total, at least 500 tillers per treatment were checked for endophyte infection in samples from Aorangi and over 900 per treatment from Lincoln samples.

\section{Invertebrates}

Surface litter was removed before the soil cores were broken up by hand and the numbers of grass grub and earthworms present were recorded. Live and uninjured grass grub were retained and later weighed. After removing subsamples for quantification of micro-organisms (Sayer et al. 2004) and nematodes (Bell 2005), roots and soil from each plot were subjected twice to a wet sieving process to extract small invertebrates. Material that was captured on both the $210 \mu \mathrm{m}$ and $710 \mu \mathrm{m}$ aperture sieves during each wet sieving was washed into separate specimen containers and refrigerated until counting. For counting, samples were diluted to give a total amount of between 30 and $60 \mathrm{ml}$ (depending on the size of the original sample) and stirred thoroughly as $5 \times 2 \mathrm{ml}$ aliquots were taken and transferred to a Petri dish with gridlines (approx. $1 \mathrm{~cm}^{2}$ ) marked on the base. Invertebrates were counted under 16x magnification. Numbers of invertebrates in the $10 \mathrm{ml}$ subsample were multiplied by the dilution factor to give a total number per sample.

\section{Mycorrhiza}

Several root segments up to $20 \mathrm{~mm}$ in length were taken at random from each of the 5 cores taken from each plot and placed together in a vial. To clear the roots prior to staining, roots in each vial were immersed in $10 \% \mathrm{KOH}$ and heated in a waterbath at $60^{\circ} \mathrm{C}$ for $4 \mathrm{~h}$. After rinsing in tap water, roots were soaked in $0.05 \%$ hydrogen peroxide for $20 \mathrm{~min}$, followed by further rinsing and then staining with aniline blue in lactoglycerol for $2 \mathrm{~h}$ at $60^{\circ} \mathrm{C}$. Roots were preserved in a lacto-glycerol solution without stain until they were examined.

To determine the presence of AM, four root segments were taken from each vial and measured before they were mounted on a slide in lacto-glycerol and examined under a microscope at 200x magnification. A visual estimate of the amount of AM present in each root segment was made on a sale of $0-5$ where $0=$ no mycorrhiza present and $5=$ mycorrhizal infection present in $80-100 \%$ of the length of the root.

\section{Analysis}

Statistical analysis was carried out by analysis of variance. Root aphid data were log transformed prior to analysis but only arithmetic means are presented. A t-test was used to compare the weights of grass grub taken from each treatment at Lincoln.

\section{RESULTS}

Endophyte infection rates at Aorangi were 4\% in E- plots, $70 \%$ in plots of tall fescue infected with AR501, and 97\% for AR542. At Lincoln, E- plots had an infection level of $1 \%$ and plots with AR501 were $80 \%$ infected.

\section{Invertebrates}

Grass grub were present in the Lincoln trial but not at Aorangi. Although there were fewer larvae found under tall fescue infected with AR501 (mean 133/m ${ }^{2}$ ) than under E- tall fescue $\left(268 / \mathrm{m}^{2}\right)$, the high variability $(\mathrm{SED}=75.7)$ between plots meant that differences were not significant $(\mathrm{P}=0.17)$. The mean weight of grass grub larvae was $155 \mathrm{mg}(\mathrm{n}=19)$ and $143 \mathrm{mg}(\mathrm{n}=23)$ respectively, for the AR501 and E- treatments $(\mathrm{P}>0.05)$. The number of earthworms taken from the soil cores also did not differ significantly between treatments at either site (Table 1). Most of the earthworms were juveniles, which made them difficult to identify, but those that could be identified in both 
treatments from Lincoln were mostly Apporectodea caliginosa with a few Lumbricus rubellus and A. longa.

Very few microarthropods were captured on the $710 \mu \mathrm{m}$ sieve so not all these samples were counted and these data have been excluded. Generally, there was a very low diversity of microarthropods with mites and Collembola dominating the invertebrate fauna at both sites (Table 1). The numbers of Collembola and mites extracted from Aorangi samples was considerably higher than numbers from Lincoln. An unidentified fly larva was also common in Aorangi samples but rare in Lincoln samples. In addition, one sciarid fly and two Staphylinid beetles were found in the Aorangi samples, while a total of four mealybug (Pseudococcidae) were found in E- plots at Lincoln and one from AR501 plots.

The root aphid, A. lentisci, was the only species affected by endophyte. Numbers of this insect were low at Aorangi but more common at Lincoln and it was at the latter site that more aphids were found under $\mathrm{E}-$ than under AR501-infected tall fescue $(\mathrm{P}<0.001)$ (Table 1).

TABLE 1: Mean number (and SEM) of different invertebrate groups found per 5 soil cores taken from under endophyte-infected (AR501 and AR542) and endophyte-free (E-) tall fescue at two field trial sites, Aorangi and Lincoln.

\begin{tabular}{lccccc}
\hline Treatment & Collembola & Mites & Earthworms & Diptera $^{1}$ & Root aphid \\
\hline Aorangi & & & & & \\
E- & $105(30)$ & $226(26)$ & $11(3)$ & $11(4)$ & $12(4)$ \\
AR501 & $57(21)$ & $187(26)$ & $13(3)$ & $4(4)$ & $3(4)$ \\
AR542 & $86(21)$ & $261(36)$ & $12(4)$ & $19(6)$ & $6(5)$ \\
Significance & ns & ns & ns & ns & ns \\
Lincoln & & & & & \\
E- & $13(5)$ & $21(9)$ & $19(4)$ & $1^{2}$ & $34(6)$ \\
AR501 & $27(5)$ & $27(9)$ & $17(4)$ & 1 & $1(6)$ \\
Significance & ns & ns & ns & & P $<0.001$ \\
\hline
\end{tabular}

${ }^{1}$ Almost all were larvae of an unidentified fly species.

${ }^{2}$ Too few to analyse.

TABLE 2: Mean proportion of root segments infected with arbuscular mycorrhiza and their mean infection score in endophyte-infected (AR501 and AR542) and endophyte-free (E-) plots at Lincoln and Aorangi

\begin{tabular}{lcccc}
\hline Treatment & $\begin{array}{c}\text { Proportion of roots } \\
\text { infected }\end{array}$ & SEM & Infection score $^{1}$ & SEM \\
\hline Aorangi & 0.66 & 0.064 & 1.4 & 0.25 \\
E- & 0.69 & 0.064 & 1.2 & 0.25 \\
AR501 & 0.78 & 0.091 & 1.4 & 0.35 \\
AR542 & $\mathrm{ns}$ & $\mathrm{ns}$ & \\
Significance & & & 2.0 & 0.117 \\
Lincoln & 0.89 & 0.029 & 2.1 & 0.117 \\
E- & 0.93 & 0.029 & $\mathrm{~ns}$ & \\
AR501 & ns & &
\end{tabular}




\section{Mycorrhiza}

The mean length of root segments inspected for AM was $9 \mathrm{~mm}$ from the Aorangi samples and $12 \mathrm{~mm}$ from the Lincoln samples. Neither the proportion of root segments infected with AM nor the level of root infection differed between $\mathrm{E}+$ and $\mathrm{E}$ - treatments at either site (Table 2). Roots from the Lincoln site were more heavily infected with AM than roots from Aorangi.

\section{DISCUSSION}

The abiotic and biotic stress tolerance provided by endophyte infection of tall fescue occurs in root systems as well as in above-ground parts of the plant. Abiotic effects include changes in root morphology and chemistry of the root surface that may increase phosphorus uptake and aluminium tolerance under certain conditions (Belesky \& Malinowski 2000). In addition, alkaloids such as lolines can be found in the roots of E+ tall fescue where they may affect root-feeding pests such as grass grub. Growth, development and survival of these insects can be reduced by some strains of endophyte in tall fescue (Popay 2004), although no significant effect of AR501 endophyte on populations of grass grub, or on the weight of individual larvae, was found here. Chemical changes in roots may also impinge, either directly or indirectly, on other soil biota which have vital roles as participants in below-ground detrital food webs. In this context it is reassuring to note that there were no overt negative impacts on the beneficial soil invertebrates, earthworms, Collembola and mites, detected in this study.

Without classification to genera or even species level, however, it cannot be assumed that there are not some subtle differences in faunal composition. Composition of surfacedwelling arachnid species differed between ryegrass paddocks with a high frequency of endophyte infection and those with a low infection rate (Prestidge \& Marshall 1997). Similarly, Bernard et al. (1997) reported that assemblages of collembolan species in the litter differed between tall fescue infected with the toxic Wild-type endophyte and E- tall fescue in a USA field study. Changes such as these could result in functional differences in litter decomposition. It has been reported that decomposition rates of litter of Italian ryegrass, Lolium multiflorum, were slower when infected with endophyte than when endophyte-free (Omacini et al. 2004). There is, however, very little information on below-ground impacts of endophyte infection on detrital food-webs. Numbers of earthworms did not differ between E- and E+ ryegrass pastures (Prestidge et al. 1997) but a similar study has not been conducted previously with tall fescue. The growth rate of the earthworm, Eisenia fetida, increased when they were fed E+ tall fescue leaf material compared with E-, suggesting that endophyte has no negative impacts at least on this earthworm species (Humphries et al. 2001).

AM colonisation of tall fescue roots can be disrupted by Neotyphodium infection, when studies have been conducted using toxic wild-type endophytes (Chu-Chou et al. 1992; Guo et al. 1992). However, there is no indication in the data from the present study that the non-toxic endophytes reduced AM infection at either site.

The root aphid, A. lentisci, is common in pasture throughout New Zealand and pot trials have indicated that, when plants are under stress, this insect may reduce growth of ryegrass (A.J. Popay, unpublished data). Populations of root aphid are reduced by $N$. uncinatum infection of meadow fescue (F. pratensis) (Schmidt \& Guy 1997) and a Neotyphodium strain, AR37, in ryegrass (Popay et al. 2004). The results presented here indicate that the non-toxic strain of Neotyphodium, AR501, in tall fescue also reduces root aphid numbers.

\section{ACKNOWLEDGEMENTS}

Thanks to Chris Pennell for sampling the Lincoln site, to David Hume and Tom Lyons for sampling Aorangi and for measuring endophyte infection rates, and to Neil Cox for statistical analysis. 


\section{REFERENCES}

Belesky DP, Malinowski DP 2000. Abiotic stresses and morphological plasticity and chemical adaptations of Neotyphodium-infected tall fescue plants. In: Bacon CW, White JF ed. Microbial Endophytes. Marcel Dekker, New York. Pp. 455-484.

Bell NL 2005. The impact of tall fescue (Festuca arundinacea) endophyte (Neotyphodium spp.) on non-target soil nematodes. New Zealand Plant Protection 58: 112-116.

Bernard EC, Gwinn Kimberly D, Pless CD, Williver CD 1997. Soil invertebrate species diversity and abundance in endophyte-infected tall fescue pastures. In: Bacon CW, Hill NS ed. Neotyphodium/Grass Interactions. Plenum Press, New York. Pp. 125-135.

Chu Chou M, Guo B, An ZQ, Hendrix JW, Ferriss RS, Siegel MR, Dougherty CT, Burrus PB 1992. Suppression of mycorrhizal fungi in fescue by the Acremonium coenophialum endophyte. Soil Biology and Biochemistry 24(7): 633-637.

Guo B, Hendrix J, An Z-Q, Ferris R 1992. Role of Acremonium endophyte of fescue on inhibition of colonisation and reproduction of mycorrhizal fungi. Mycologia 84: 882-885.

Hahn H, Huth W, Schoberlein W, Diepenbrock W 2003. Detection of the endophytic fungi in Festuca spp. by means of tissue print immunoassay. Plant Breeding 122: 217-222.

Humphries SS, Gwinn KD, Stewart AJ 2001. Effects of endophyte status of tall fescue tissues on the earthworm (Eisenia fetida). Environmental Toxicology and Chemistry 20: $1346-1350$.

Omacini M, Chaneton EJ, Ghersa CM, Otero P 2004. Do foliar endophytes affect grass litter decomposition? A microcosm approach using Lolium multiflorum. Oikos 104: 581-590.

Popay AJ 2004. Response of black beetle (Heteronychus arator), porina (Wiseana cervinata) and grass grub (Costelytra zealandica) to different endophytes in tall fescue. Proceedings of the 8th Australasian Grassland Invertebrate Ecology Conference. Pp. 157-163.

Popay AJ, Silvester WB, Gerard PJ 2004. New endophyte isolate suppresses root aphid, Aploneura lentisci, in perennial ryegrass. In: Kallenbach R, Rosenkrans CJ, Lock TR ed. 5th International Symposium on Neotyphodium/Grass Interactions. Fayetteville, Arkansas. p. 317.

Prestidge RA, Marshall SL 1997. The effects of Neotyphodium-infected perennial ryegrass on the abundance of invertebrate predators. In: Bacon CW, Hill NS ed. Neotyphodium/Grass Interactions. Plenum Press, New York. Pp. 195-197.

Prestidge RA, Marshall SL, Thom ER 1997. Seasonal earthworm densities on endophyteinfected and endophyte-free perennial ryegrass. Proceedings of the 50th New Zealand Plant Protection Conference. Pp. 73-77.

Sayer ST, Burch G, Sarathchandra SU 2004. The impact of tall fescue (Festuca arundinacea) endophyte (Neotyphodium spp.) on non-target soil micro-organisms. New Zealand Plant Protection 57: 329-336.

Schmidt D, Guy PL 1997. Effects of the presence of the endophyte Acremonium uncinatum and of an insecticide treatment on seed production of meadow fescue. Revue Suisse d'Agriculture 29: 97-99. 